\title{
KONFLIK PENDUDUK ASLI DENGAN WARGA PENDATANG DI PONDOK AREN, TANGERANG SELATAN
}

\author{
Dudi Iskandar dan Indah Suryawati \\ Fakultas Ilmu Komunikasi Universitas Budi Luhur Jakarta \\ dudisabiliskandar@yahoo.com, indahsuryawati_2121@yahoo.com
}

\begin{abstract}
ABSTRAK
Komunikasi trans budaya merupakan salah satu bentuk komunikasi untuk menjembatani perbedaan dalam berbagai aspek. Sebab perbedaan tersebut kerap menimbulkan gesekan dan konflik. Sebagaimana konflik berlatar budaya antara warga asli dan warga pendatang di Pondok Aren. Kehadiran komunikasi trans budaya menjadi sangat penting dalam membangun kehidupan yang harmonis antara keduanya. Oleh karena itu, penelitian ini menggunakan metode kualitatif deskripsi untuk meneliti kondisi obyek yang alamiah dengan kekuatan pada deskripsi kata-kata bukan pada kepastian melalui kata-kata. Hasil penelitian menjelaskan bahwa konflik berlatar budaya antara warga asli dan warga pendatang di Pondok Aren sesungguhnya bisa diselesaikan secepatnya. Kuncinya terletak pada kemauan berdialog, bernegosiasi, dan adanya keterlibatan struktur negara. Dan pendekatan komunikasi trans budaya adalah kunci penyelesaian konflik antara warga asli dan warga pendatang di Pondok Aren.
\end{abstract}

Kata kunci : Komunikasi trans budaya, konflik, budaya

\begin{abstract}
Cross culture communication is one kind of communication to bridge the differences in various aspects. Because of these differences often cause friction and conflict. As the conflict cultural conflict background between natives and migrants in Pondok Aren. The presence cross culture communication becomes very important to build a harmonious life between those of two. Therefore, this study used qualitative methods to examine the condition of the description of natural objects with the power of words description rather than on certainty through words. The results of the study explained that the cultural background of conflict between natives and migrants in Pondok Aren can actually be resolved as soon as possible. The key lies in the willingness to dialogue, negotiate, and the involvement of state structures. And cross culture communication approach is the key solution to the conflict between natives and migrants in Pondok Aren.
\end{abstract}


Keywords: cross culture communication, conflict, culture

\section{PENDAHULUAN}

Perbedaan adalah hukum alam. Ia sesuatu yang niscaya dalam kehidupan ini.. Perbedaan bisa melahirkan kerja sama atau konflik. Pilihan kerja sama atau konflik tergantung manusia yang memilihnya : apakah perbedaan dikelola sebagai potensi positif atau negatif?

Dalam konteks budaya, perbedaan adalah khasanah multikulturalisme yang harus dirawat untuk keberlangsungan hidup dan kehidupan manusia. Multikulturalisme bisa didefinisikan menghormati hak-hak untuk berbeda secara budaya (the right of cultural diversity). ${ }^{1}$ Multikulturalisme menganggap etnosentrisme, xenosentrisme, maupun xenofobia bukan tutur kata dan sikap yang harus dipertahankan. Justeru menghormati hak-hak atas keanekaan budaya atau hak-hak untuk berbeda secara budaya adalah yang patut dikedepankan. Dalam tataran yang paling praktis multikulturalisme menunjukkan penyesuaian budaya melalui dialog pengalaman pribadi dan kelompok. Dialog yang merupakan bagian dari komunikasi merupakan cara terbaik dalam mengelola perbedaan sehingga menjadi energi positif. Dalam konteks inilah komunikasi menemukan signifikansinya. $^{2}$

Untuk mencapai komunikasi multikultur yang ideal tahapan pertama adalah menyatukan visi. Perumusan visi adalah proses yang menyatukan mozaik dan nilai menjadi sebuah kerangka yang diterima semua pihak. Dan, visi bangsa kita sudah selesai dan final, yaitu Pancasila. Dengan demikian yang menjadi pekerjaan rumahnya adalah implementasi visi tersebut dalam gerak langkah keseharian.

Proses komunikasi multikultur akan bermakna dan berlangsung mulus jika kita memiliki kompetensi komunikasi. Kompetensi, kata Webster's (1997) yang dikutip Alo Liliweri adalah state of being capable. Suatu keadaan yang menunjukkan kapabelitas atau kemampuan sehingga dapat berfungsi dengan caracara yang mendesak dan penting. Kompetensi komunikasi mencakup motivasi, pengetahuan, keterampilan, dan konteks sosial budaya. Pengetahuan merupakan faktor dominan yang menentukan kompetensi komunikasi. Pengetahuan berkaitan erat dengan tingkat kesadaran seseorang terhadap apa yang dibutuhkan seseorang ketika berkomunikasi dengan orang lain.

Dalam skala mikro, pengembangan dan pembangunan komunikasi antarbudaya harus terus didengungkan. Bahwa harmonisasi kehidupan hanya bisa dilakukan jika melakukan komunikasi, khususnya komunikasi antarbudaya.

${ }^{1}$ Kristianto, JB, dkk (editor), 2004, Esai-esai Bentara, Kompas, Jakarta

2 Baran, J. Stanley, 1999, Introduction to Mass Communication: Media Literacy and Culture, Mc Graw-Hill, Boston. 
Komunikasi menjadi faktor utama untuk membangun kesepahaman seperti dari kata aslinya communis yang berarti sama.

Komunikasi transbudaya merupakan salah satu bentuk komunikasi untuk menjembatani perbedaan dalam berbagai aspek. Etnis, ras, agama, status sosial ekonomi, dan bahkan pandangan politik. Oleh sebab itu, kehadiran komunikasi transbudaya menjadi sangat penting dalam membangun kehidupan yang harmonis dalam berbagai aspek kehidupan manusia. Karena seperti dikemukakan di awal tulisan, hidup ini indah jika berbeda. Perbedaan adalah keharusan. Ia bukan sesuatu yang bisa dihindari tetapi harus dikelola, khususnya, dengan dan melalui komunikasi transbudaya.

Salah satu pemicu konflik antarbudaya adalah kehadiran berbagai kompleks perumahan, khususnya pinggiran Ibu Kota Jakarta. Konflik antara penduduk asli yang mayoritas beretnis Betawi dan warga pendatang yang kebanyakan kaum urban. Mereka datang dari berbagai wilayah di Indonesia. Kaum urban ini menemukan sumber kehidupannya (pekerjaan) di wilayah Jakarta, namun memiliki atau tinggal di perumahan yang ada di pinggiran Jakarta yang lingkungan sekitar tempat mereka tinggal mayoritas penduduk aslinya beretnis Betawi.

\section{KERANGKA PEMIKIRAN}

\section{Teori Face Negotiation ${ }^{3}$}

Teori ini ada ketika beberapa dekade yang lalu masyarakat mengalami konflik dan mereka ingin menanggulangi konflik tersebut. Teori menjelaskan akar konflik didasarkan pada identitas manajemen pada tingkat individu dan budaya. Berbagai aspek dari individu dan identitas budaya yang digambarkan sebagai wajah. Wajah adalah gambar dari seorang individu atau kelompok masyarakat yang mereka melihat dan menilai berdasarkan norma-norma dan nilai-nilai budaya. Konflik yang terjadi ketika individu atau kelompok memiliki wajah yang seperti terancam.

Face Negotiation Theory dikemukakan pertama kali oleh Stella TingToomey. Teori ini membantu mengelola konflik budaya yang berbeda dalam aspek komunikasi, selain itu teori ini dikembangkan sebagai cara untuk memprediksi bagaimana seseorang akan menyempurnakan identitas mereka dalam kebudayaan yang berbeda. Sifat alami yang akan muncul pada tiap orang adalah bagaimana mereka memperlihatkan identitas mereka dan bisa dianggap keberadaannya oleh orang lain. Face, atau bisa juga disebut sebagai pencitraan

\footnotetext{
${ }^{3}$ Disarikan dari A First Look at Communication Theory, EM Griffin, Seventh Edition, McGraw-Hill, New York, 2009
} 
diri atau rasa positif yang tertanam dalam diri kita mengenai budaya kita saat kita dikenalkan atau berada dalam budaya lain. Sedangkan facework merupakan perilaku komunikasi yang bertujuan untuk melindungi pencitraan diri kita di depan orang lain. Dalam teori ini, terdapat dua aspek penting, yaitu rasa individualism-kolektivisme dan kekuatan jarak.

Menurut seorang psikolog dari Universitas Illionis Harry Triandis menyatakan terdapat tiga perbedaan penting dalam kolektivisme dan individualisme. Perbedaan itu adalah mengenai arti dari diri (self), tujuan (goals) dan kewajiban (duty). Seorang kolektivis akan menganggap dirinya sebagai seorang mahasiswa, anak, seorang muslim dan perempuan. Akan tetapi seorang yang individualis akan menganggap dirinya sebagai dirinya sendiri, tidak terpengaruh dan bergantung dengan lingkungan yang menyokongnya. Seorang kolektivis tidak akan pernah melawan tujuan dari kelompok, dia akan berjalan dengan tujuan kelompoknya. Berlawanan dengan seorang individualis yang memang akan lebih menonjolkan kepentingan pribadinya. Lalu seorang kolektivis akan bersosialisasi untuk menikmati kewajiban mereka yang ada untuk melayani atau membantu orang lain, sedangkan individualis akan bekerja dengan prinsip yang minim untuk membedakan mana kesenangan dan mana keuntungan untuk diri sendiri.

Setiap individu memiliki pengaruh dalam setiap pembuatan keputusan di kelompoknya. Akan tetapi, perilaku individu tersebut diikat norma yang ada dalam kelompok tersebut. Hal ini juga biasa disebut dengan identity. Berbanding terbalik dengan budaya di atas kepentingan individu justru lebih diperhatikan dibandingkan dengan kepentingan kelompok. Mereka hidup dengan aturan yang mereka buat sendiri dan cenderung tidak peduli dengan orang lain. Dengan adanya perbedaan kultur seperti ini, tentu saja konflik yang dimiliki oleh tiap daerah akan berbeda.

Menurut professor manajemen dan pemasaran di Universitas Western Kentucky M. Afzalur Rahim, Ting-Toomey mengidentifikasi lima respon yang berbeda saat situasi seseorang tidak meraih kebutuhan, kepentingan atau tujuan mereka. Yaitu,

a) Avoiding (menghindar), seseorang akan berusaha menghindari konflik yang sekiranya akan menyulitkan dirinya.

b) Obliging (menurut, membantu), seseorang menawarkan bantuan kepada orang lain karena ada rasa prihatin atau iba.

c) Compromising (kompromi), mengambil pendekatan kedua belah pihak memberikan sesuatu dalam rangka menemukan jalan tengah dan mencapai solusi. 
d) Dominating (dominasi), seseorang yang memiliki dominasi akan menekan pihak lain dengan kekuatan yang dimilikinya.

e) Integrating (mempersatukan), merupakan win-win solution yang bermanfaat untuk kedua belah pihak dan menjadi solusi yang baik.

Teori Face Negotiation memiliki tiga asumsi yang pada intinya terdiri dari konsep kunci teori ini, yaitu wajah, konflik dan budaya:

1. Identitas diri merupakan sesuatu hal yang penting penting di dalam interaksi interpersonal. Namun dalam interaksinya, individu-individu menegosiasikan identitas mereka secara berbeda sesuai dengan budaya asalmereka.Melekat dengan asumsi pertama adalah keyakinan bahwa para individu di dalam semua budaya memiliki beberapa citra diri yang berbedadan bahwa mereka menegosiasikan citra ini secara terus-menerus. Dalam banyak budaya yang berbeda, orang-orang membawa citra yang merepresentasikan kepada orang lain secara kebiasaan atau strategis.

2. Konflik merupakan peristiwa yang dapat merusak dan menyebabkan kerenggangan antar orang yang semula berhubungan sangat dekat. Dalam konteks ini, konflik yang terjadi memiliki hubungan yang sangat erat dengan wajah dan budaya. Hal ini dikarenakan cara seseorang menghadapi dan meyelesaikan konflik sangat berhubungan erat dengan cara bagaimana ia dibesarkan. Atau dengan kata lain, orang yang dibesarkan dalam kebudayaan barat memiliki cara mengatasi konflik yang berbeda dengan orang yang dibesarkan dalam kebudayaan timur.

3. Ketiga berkaitan dengan dampak yang dapat diakibatkan oleh suatu tindakan terhadap muka. Setiap orang memiliki kemampuan untuk menampilkan beraneka macam ekspresi. Menurut asumsi ini, terdapat dua pola dalam face threatening process yaitu face saving \& face restoration. Face saving merupakan usaha untuk mencegah terjadinya sesuatu yang memalukan sedangkan face restoration merupakan strategi yang dilakukan untuk melindungi otonomi atas diri sendiri dan mencegah jatuhnya harga diri karena malu.

\section{METODE PENELITIAN}

Penelitian ini menggunakan metode kualitatif deskriptif. Penelitian kualitatif deskripsi adalah metode yang digunakan untuk meneliti kondisi obyek yang alamiah dengan kekuatan pada deskripsi kata-kata bukan pada kepastian melalui kata-kata. Karakteristik yang paling mendasar dari penelitian kualitatif 
adalah realitas dikonstruksi secara sosial; berdasarkan kesepakatan bersama. ${ }^{4}$ Penelitian kualitatif bermaksud memahami fenomena yang dialami subjek penelitian. Ia mendeskripsikan secara holistik sikap, motivasi, tindakan dengan latar belakang alamiah dan dalam bentuk kata-kata. ${ }^{5}$

Pendekatan ini digunakan untuk mencari dan menemukan pengertian atau pemahaman tentang fenomena dalam suatu latar yang berkonteks khusus. Penelitian kualitatif yang bertujuan memahami fenomena komunikasi yang terjadi. $^{6}$ Dalam kualitatif ini peneliti menjadi instrumen kunci, teknik pengumpulan data dilakukan secara gabungan dan lebih menekankan makna. Data yang tersedia diolah digambarkan, dipaparkan, dianalisis, dan dideskripsikan.

Peneliti adalah instrumen kunci dalam penelitian kualitatif-deskiptif. Oleh sebab itu, penelitian ini berangkat dari pengamatan/observasi partisipan dan nonpartisipan terhadap objek penelitian. Tahap selanjutnya adalah wawancara mendalam untuk memperoleh data yang lebih akurat dan menyentuh pada pemecahan masalah penelitian. Hasil observasi dan wawancara diperkuat dengan data pustaka yang ada dalam kerangka teoritis. Dengan demikian, akan diperoleh data hasil penelitian, pembahasan, dan kesimpulan yang integral dan komprehensif.

\section{HASIL PENELITIAN DAN PEMBAHASAN \\ Hasil Penelitian}

Kompleks Puri Bintaro Hijau terletak di dua Kota (daerah tingkat II). Sebagian terletak di Kota Tangerang dan ada juga yang masuk Kota Tangerang Selatan. Yang termasuk di Kota Tangerang adalah Blok H-J. Sedangkan Blok A$\mathrm{G}$ berada di wilayah Tangerang Selatan (sebelumnya ada Tangerang Selatan Blok A-G merupakan wilayah Kabupaten Tangerang. Sejak pemekaran Kabupaten Tangerang dan Kota Tangerang Selatan, Blok A-G menjadi bagian Kota Tangerang Selatan.

Blok H-J berbatasan dengan Kelurahan Peninggilan, Cileduk. Yang menjadi pembatas dengan Blok A-G (sekaligus pembatas antara Kota Tangerang dan Tangerang Selatan) hanyalah jalan. Karena berada di dua wilayah taingkat II inilah banyak yang salah mengerti kalau mencari alamat di Kompleks Puri Bintaro Hijau.

Blok A-G Kompleks Puri Bintaro Hijau tepatnya terletak di Kelurahan dan Kecamatan Pondok Aren. Ia berbatasan dengan Kampung Kebanten yang terdiri

4 Deddy Mulyana dan Solatun, 2013, Metode Penelitian Komunikasi. Bandung. Remaja Rosdakarya : 4

${ }^{5}$ Lexy Meleong, 2010, Metodologi Penelitian Kualitatif. Bandung. Remaja Rosda Karya : 6

${ }^{6}$ Pawito. 2008. Penelitian Komunikasi Kualitatif. Yogyakarta. LkiS : 35 
dari beberapa RW. Sepanjang perbatasan Blok A-G Kompleks Puri Bintaro Hijau selalu beririsan dengan Kampung Kebantenan. Lumrah bila interaksi kerap terjadi di antara dua kelompok warga tersebut.

Seperti lazimnya kompleks perumahan, warga Kompleks Puri Bintaro Hijau juga plural dan majemuk dari berbagai aspeknya. Pekerjaan, status sosial, budaya dan tentu saja asal daerah. Sebagai warga baru di Pondok Aren, tentu saja mereka harus bergaul sesamanya sehingga menimbulkan kohesivitas untuk kepentingan bersama. Secara lebih jauh kohesivitas ini dibangun oleh tema fantasi yang sama seperti dalam teori konvergensi simbolik. ${ }^{7}$

Kemajemukan inilah yang nyaris tidak dimiliki warga asli Kebantenan, Pondok Aren. Dari sudut etnis penduduk kampung ini homogen, yakni Betawi pinggiran. Sedangkan pekerjaan adalah mayoritas buruh dan pedagang. Hanya sedikit saja yang bekerja di kantor (kerja kantoran dalam istilah Betawi). Kohesivitas juga dibangun penduduk asli Kebantenan meski tidak memiliki fantasi yang sama seperti dalam teori konvergensi simbolik.

Perbedaan dua kondisi (sosial, ekonomi, status sosial, pendidikan, dan budaya) yang berbeda inilah yang kerap menimbulkan gesekan dan konflik. Sehingga dalam beberapa kesempatan sempat terjadi ketengangan dalam masalah yang melibatkan kedua belah pihak. Misalnya, penggunaan jalan. Di satu sisi, misalnya, Kompleks Puri Bintaro Hijau menginginkan wilayahnya diportal, namun didi sisi lain, warga Kebantenan, keberatan karena akses mereka terganggu atau terbatas.

Salah satu wilayah yang kerap berkonflik adalah warga Blok F dengan warga Kampung Kebantenan. Blok F merupakan wilayah terluas di Kompleks Puri Bintaro Hijau. Ada beberapa rumah dibangun pengembang, PT Sarana Jaya. Ada juga yang masih kampling tanah yang diperjualbelikan. Dalam beberapa kesempatan konflik ini terselubung, tetapi dalam beberapa kesempatan menjadi konflik yang terbuka meski tidak menimbulkan korban.

Sesungguhnya hubungan antara mereka tidak bisa dilihat sesama tunggal. Ia merupakan fenomena yang sangat kompleks. Konflik ini tidak bisa dipotret secara hitam putih atau berhadapan langsung. Selalu ada sisi-sisi lain yang beririsan secara positif di antara kedua belah pihak. Misalnya, keluarga perumahan yang suami istrinya sibuk bekerja membutuhkan asisten rumah tangga. Solusinya adalah mencari di sekitar. Selain harganya lebih mudah daripada mengambil dari agen, ia bisa dikontrol dan lebih dipercaya. Begitu juga dengan tenaga keamanan (satuan pengamanan). Lazimnya di semua perumahan,

7 Stephen W. Littlejohn and Karen A. Foss, Theories of Communication, Edisi 9, penerjemah Mohamad Yusuf Hamdan, Salemba Humanika, Jakarta, 2009: 236 
kehadiran satpam adalah mutlak dibutuhkan. Lagi-lagi semua RT (13 RT) dari Blok A-G dan Blok I-J (2 RT) mengambil tenaga satpam dari warga setempat. Kerja sama lain adalah di bidang keagamaan. Pendekatan kultural seperti tahlilan, marhaba, dan pengajian adalah efektif menembuh sekat-sekat kultural di antara dua kutub yang berbeda.

\section{Pembahasan}

Ketika sebuah kompleks perumahan,---khususnya di daerah pinggiran Jakarta yang banya dihuni etnis Betawi-berdirikan implikasi negatif yang timbuh adalah timbunya konflik antar penduduk asli Betawi dan warga kompleks yang mayoritas pendatang dari berbagai penjuru Nusantara. Konflik ini timbul karena beragam faktor. Perbedaan kultur asal usul wilayah, dan perbedaan bahasa, contohnya. Oleh sebab itu, nyaris di semua perumahan di wilayah pinggiran Jakarta tumbuh konflik.

Dalam konteks konflik budaya antara warga Blok F Puri Bintaro Hijau dan warga asli Betawi yang tinggal Kebantenan, ada beberapa faktor pemicunya. Antara lain,

\section{Penggunaan kata "Warga Kompleks" dan "Warga Kampung"}

Kata "Warga Kompleks" dan "Warga Kampung" adalah dua terminologi yang mensinyalir streotype. Bahwa "Warga Kompleks" identik dengan orang kaya, memiliki pekerjaan mapan, status sosial yang tinggi, dan terhormat. Dan yang terpenting serta menjadi faktor utama pemicu konflik adalah "Warga Kompleks" adalah warga pendatang. Ia bukan asli atau bukan penduduk Pondok Aren. Padahal Kartu Tanda penduduk (KTP) dan berbagai dokumen pribadi dan keluarga "Warga Kompleks" adalah Pondok Aren. Namun, stigma warga "Warga Kompleks" bukan warga asli menjadi pemantik konflik terbesar.

Di sisi lain, "Warga Kampung" adalah mereka yang berada di luar kompleks Perumahan Puri Bintaro Hijau, terlepas ia bukan penduduk asli atau pendatang. Terminologi “warga Kampung” cenderung menandaskan inferioritas. Misalnya, sebagai penduduk asli, bodoh, miskin, dan tidak punya pekerjaan tetap. Padahal, tentu saja dua terminologi dan beragam karakteristiknya tersebut salah kaprah. Karena pada kenyataanya karakteristik kedua istilah tersebut sangat kabur. Banyak warga asli Bewati (Kebantenan) yang kaya, status sosial tinggi, dan memiliki jabatan tinggi di tempat kerja mereka. Pun, sebaliknya, ada bahkan mungkin banyak "Warga Kompleks" yang tidak seideal dipikirkan "Warga Kampung"

Bahasa adalah salah satu ekspresi verbal manusia. Ia ada dan keluar dari manusia sebagai ungkapkan berbegai fungsi. Salah satunya fungsi tranformasi 
informasi. Bahasa bukan sesuatu yang lahir di ruang hampa. Ia selalu dalan konteks tertentu. Di situ ada situasi, kondisi, partisipasi, dan intertektualitas. ${ }^{8}$

Bahasa kemudian membentuk wacana (discourse). Ia berasal dari bahasa Latin, Discursus. Artinya "dis" dari dalam arah yang berbeda dan currere yang berarti lari. Kamus mendenisikan discourse dengan percakapan. Pada awalnya analisis wacana digunakan untuk penelitian linguistik. Ia membatasi pada penganalisaan kalimat. Teori wacana ingin menjelaskan sebuah peristiwa seperti terbentuknya kalimat atau pernyataan.

Menurut Pawito, ${ }^{9}$ dalam mengenai beberapa kenyakinan mengapa melakukan penelitian dengan wacana. Yakni, komunikasi terdiri dari tindakantindakan kompleks yang kemudian membentuk pesan yang mana mengandung wacana atau wacana-wacana tertentu. Kedua, manusia terikat ketentuan ketika menggunakan bahasa, menggunakan wacana atau melakukan tindakan. Ketiga, komunikator menggunakan wacana untuk mencapai tujuan,dan cara yang ditempuh biasanya terikat oleh ketentuan-ketentuan. Ketiga, kendati bahasa, dan sistem simbol lainnya adalah wujud nyata dari aktivitas komunikasi, wacana yang menjadi materi dari komunikasi.

Ibnu Hamad ${ }^{10}$ membedakan pengertian discourse dalam dua pengertian. Pertama, discourse (dengan d kecil) yang melihat bagaimana bahasa digunakan pada tempatnya untuk memerankan kegiatan aspek kebahasaan. Kedua, Discourse (dengan D besar) yang merangkai unsur discourse (dengan d kecil) bersama unsur non-linguistik untuk memerankan kegiatan, pandangan, dan identitas. Beberapa bentuk non bahasa antara lain ideologi, ekonomi, politik, budaya, dan sebagainya. Dalam politik, analisis wacana adalah praktik pemakaian bahasa, terutama bahasa politik. $^{11}$

J.S. Badudu seperti dikutip Eriyanto $^{12}$ secara komprehensif mendefinisikan wacana dalam dua bentuk. Yakni, sebagai rentetan kalimat yang saling berkaitan. Ia menghubungkan proposisi yang satu dengan yang lain sehingga membentuk kesatuan struktur sehingga ada keserasian di natara kalimatkalimat tersebut. Kedua, wacana sebagai kesatuan bahasa yang tertinggi dan terlengkap. Ia berada di atas klausa dengan koherensi dan kohesi tinggi yang berkesinambungan. Ia memiliki awal dan akhir yang nyata disampaikan baik secara lisan maupun tulisan.

\footnotetext{
${ }^{8}$ Guy Cook, The Discourse of Advertising, Raoutledge, London and New York,1994:3

${ }_{9}^{9}$ Metodologi Penelitian Kualitatif, LKiS, Yogyakarta, 2007: 175-176

${ }^{10}$ Komunikasi sebagai Wacana, La Tofi Enterprise, Jakarta, 2010:39-40

11 Eriyanto, Analisis Wacana, LKiS, Yogyakarta, 2001:3

${ }^{12}$ Analisis Wacana, LKiS, Yogyakarta, 2001:2
} 
Terminologi "Warga Kompleks" dan "Warga Kampung" bermula dari bahasa dan kata kemudian membentuk wacana. Struktur wacana "Warga Kompleks" dan "Warga Kampung" menjadi pemicu konflik antara warga asli dan warga pendatang.

\section{Pertarungan Logika Kekuatan versus Kekuatan Logika}

"Warga Kampung" tidak mengenal Ruang Terbuka Hijau (RTH) seperti yang dimiliki "Warga Kompleks." RTH adalah hak "Warga Kompleks" karena merupakan kewajiban pengembang untuk menyediaknnya. Sesuai dengan Undang-Undang RTH ini minimal 20 persen dari total wilayah kompleks perumahan walaupun pada kenyataannya banyak pengembang yang melanggarnya.

Penggunaan kata "Warga Kampung" dan "Warga Kompleks" pun berimbas pada aspek lain, yakni, penggunaan terminologi dan istilah lain. "Warga Kampung" menggunakan logika kekuatan (kekuatan otot) sedangkan "Warga Kompleks" mengedepankan kekuatan logika (rasio). Akibatnya perbedaan penggunaan alat tersebut, masalah kemudian berulang terjadi. Di sisi lain, untuk menyelesaikan masalah pun kerap berbenturan.

Salah satu contohnya adalah jalan kompleks perumahan Puri Bintaro Hijau yang dijadikan tempat parkir oleh "Warga Kampung" yang memiliki mobil. Mereka tidak izin kepada warga atau RT/RW "Warga Kompleks." Ketika diperingatkan, "Warga Kampung" yang memiliki kendaraan lebih galak daripada pemiliknya. Mereka mengajak berkonflik fisik lebih panjang. Kondisi ini berlangsung hingga kini.

Sebagai simbol logika kekuatan adalah mereka mendirikan pos ormas (FBR) dan pasar malam di jalan kompleks perumahan. Tentu saja aktivitas pasar malam tersebut menggangu ketenangan warga. Pun, mengganggu akses jalan yang akan dilewati warga yang hilir-mudik keluar kompleks perumahan. Sama seperti lahan parkir, pasar malam dan FBR pun sudah didialogkan berulang kali. Akhirnya setelah dialog yang panjang, "Warga Kompleks" harus membayar Rp10 juta sebagai kompensasi pembongkaran pos FBR. Sesuatu yang illogical. Inilah simbol kekalahan kekuatan logika oleh logika kekuatan.

Pemicu konflik yang lain adalah penjebolan tembok pembatasan oleh "Warga Kampung" tanpa izin "Warga Kompleks." Seperti lumrahnya kompleks perumahan di manapun, pasti memiliki tembok pembatas. Pengembang membangun tembok tersebut sebagai pembatas pun sebagai faktor keamanan penghuninya. Tembok pembatas ini sebagai akses keluar "Warga Kampung" menuju jalan besar raya dimiliki kompleks perumahan. Hingga saat ini ada puluhan jalan tikus sebagai akses keluar dari kompleks akibat penjebolan tembok perumahan. 
Motif lain penjebolan tembok adalah faktor ekonomi. Dengan adanya akses jalan ke kompleks harga jual tanah "Warga Kampung" meningkat berlipat. Pun, munculnya kontrakan milik "Warga Kampung" dengan akses dari kompleks.

Faktor budaya lain menyebabkan konflik adalah drainase atau saluran air. Karena letak rumah yang tidak tertata dan kian sempitnya lahan, "Warga Kampung" kesulitan untuk membuah limbah air bekas rumah tangga. Sebab tidak di "Warga Kampung" tidak tersedia drainase atau solokan untuk menampung dan mengalirkan limbah rumah tangga. Dengan kehadiran kompleks yang memiliki salurah air atau drainase bagus, maka saluran air "Warga Kampung" membuang airnya ke got milik "Warga Kompleks." Celakanya hal ini dilakukan tanpa izin "Warga Kompleks" Tentu saja bagi penghuni kompleks perilaku ini tidak bisa diterima. Bahkan, bisa dianggap sebagai penghinaan karena membuang sampah domestik berupa air comberan ke depan rumah warga kompleks.

Masalah lain adalah "Warga Kampung" menggarap lahan kosong di kompleks untuk pertanian. Ketika tanah tersebut mau dibangun meminta uang kerohiman karena sudah membersihkannya. Mereka menggarap tanah kosong di kompleks itu karena menganggap tanah yang sudah dijualnya adalah tanah leluhurnya.

Selain menggarap lahan milik warga, "warga Kampung” pun memanfaatkan lahan fasilitas umum dan fasilitas sosial warga kompleks perumahan. Pinggiran sungai yang akan dipakai warga untuk membangun fasilitas sosial taman, jogging track, dan arena bermain anak-anak) tidak bisa dimanfaatkan karena sudah terlebih dahulu dijadikan lahan pertanian/perkebunan oleh warga setempat. Sempat diberikan "uang kerohiman" untuk tidak menggarap lahan tersebut. Mereka mengikuti anjuran tersebut, tetapi itu hanya berlaku satu atau dua bulan. Setelah "uang kerohiman" itu habis mereka kembali menggarap lahan fasum/fasos tersebut. Tentu saja perilaku tersebut menjengkelkan "Warga Kampung."

Seperti disebutkan di atas, tidak semua "Warga Kampung" miskin. Buktinya mereka banyak yang memiliki rumah bagus dan mobil. Namun yang menjadi persoalan bagi mereka adalah tidak ada akses jalan untuk mobil mereka. Pun, mereka tidak memiliki garasi. Nah, begitu berdirinya komplek, maka jalan kompleks menjadi akses ke rumahnya. Pun, jalan warga dijadikan tempat parkir. "Ya amal saja atuh," begitu celetukan salah seorang "Warga Kampung" ketika ditegur karena memparkir mobil di jalan kompleks perumahan.

\section{Superioritas vs Inferioritas}

Dari penyebutan "Warga Kampung" dan "Warga Kompleks" ternyata berimplikasi kepada mental dan sikap masing-masing pihak. Di satu sisi, "Warga Kampung" merasa superior karena asli lahir dan besar di wilayah Pondok Aren. 
Sedangkan "Warga Kompleks" merasa superior karena memiliki kekuatan hukum positif atas segala fasilitas yang dipergunakan "Warga Kampung," pada sisi yang lainnya.

Kejadiran organisasi kemasyarakatan seperti Forum Betawi Rembug (FBR) di areal komplek perumahan, misalnya, bisa dilihat dua sisi. Di pihak, kehadiran FBR dan Forkabi bisa dipandang sebagai tameng untuk melindungi ketakutan tersingkir/tersisih dalam pergaulan. Di pihak lain, kehadiran ormas tersebut untuk menunjukkan eksistensi diri di tengah kian tersisih oleh kahadiran penduduk pendatang yang berada di kompleks perumahan. Superioritas ini terkadang didukung oleh aparat kelurahan yang nota bene berasal dari "Warga Kampung"

Sedangkan inferioritas juga tumbuh di benak kedua belah pihak. "Warga Kompleks" merasa inferiorir jika diajak berhadapan dalam hal kekuatan fisik. Mereka menyadari sebagai warga pendatang meski sudah memiliki KTP Pondok Aren. Sebaliknya, "Warga Kampung" inferior karena berada di bawah dalam beragam aspek kehidupan bermasyarakat (status sosial, pendidikan, dan keluasan pergaulan, misalnya).

\section{Keterlibatan Struktur Negara}

Konflik di masyarakat manapun tidak bisa dilepaskan dari aktor bernama aparat negara. Struktur negara dari berbagai tingkatan dipastikan terlibat. Dalam konflik antara "Warga Kampung" dan "Warga Kompleks" di Pondok Aren, keterlibatan aparat desa dan kecamatan tidak terhindarkan. Ada aparat desa yang mengambil keuntungan dari konflik ini untuk melanggengkan kekuasaannya. Aparat kepolisian di tingkat Polsek dan Polres terlihat jeri untuk berhadapan organisasi kemasyarakatan seperti FBR yang meresahkan warga komplek perumahan.

Berbagai laporan dan dialog yang diselenggarakan terganjal oleh keberpihakan struktur negara kepada salah satu pihak. Akibatnya, penyelesaian selalu menemui jalan buntu. Perbedaan kepentingan, khususnya dukungan terhadap kelanggengan kekuasaan menjadi penyebab utamanya. Di sinilah struktur negara menciptakan kelanggengan konflik antara "Warga Kampung" dan "Warga Kompleks"

\section{KESIMPULAN}

Sebagai catatan akhir dari penelitian ini, penegasan bahwa konflik berlatar budaya antara warga asli dan warga pendatang di Pondok Aren sesungguhnya bisa diselesaikan secepatnya. Kuncinya terletak pada kemauan berdialog, bernegosiasi, dan adanya keterlibatan struktur negara. Perbedaan budaya yang membentuk inferioritas vs superioritas, menjelma kekuatan logika versus logika kekuatan, penggunaan bahasa "Warga Kampung" vs "Warga Kompleks" adalah 
bentuk ekspresi dan simbol yang bisa diubah. Pendekatan komunikasi transbudaya adalah kunci penyelesaian konflik serupa di berbagai wilayah di Indonesia.

Perbedaan budaya antara "Warga Kampung" versus "Warga Kompleks" di Pondok Aren hanyalah potret kecil dari sebuah kemajemukan negeri ini. Di luar Pondok Aren, masih banyak rekaman konflik antarbudaya yang membahayakan kehidupan berbangsa dan bernegara. Oleh sebab itu, sudah selayaknya semua anak bangsa menyadari berbeda bukan berarti bertentangan; bersama bukan berarti satu tujuan. Berbeda untuk kebersamaan yang indah dalam segalanya. Semoga.

\section{UCAPAN TERIMA KASIH}

Penulis menyampaikan rasa terima kasih yang sebesar-besarnya kepada seluruh pihak yang telah turut membantu penyelesaian artikel ini. Khususnya kepada Ketua RT 04/12, Pondok Aren, periode 2014-201 Syahriza, beberapa warga kompleks perumahan Puri Bintaro Hijau yang bersedia diwawancarai, dan tokoh masyarakat Kebantenan H. Naman, yang dengan baik hatinya dapat meluangkan waktu untuk berbagi informasi sehingga artikel ini dapat diselesaikan.

\section{DAFTAR PUSTAKA}

Baran, J. Stanley, 1999, Introduction to Mass Communication: Media Literacy and Culture.

Cook, Guy, 1994, The Discourse of Advertising, Raoutledge, London and New York.

Eriyanto, 2001, Analisis Wacana, LKiS, Yogyakarta.

Griffin, Em, 2009, A First Look at Communication Theory, EM Griffin, Seventh Edition, McGraw-Hill, New York.

Hamad, Ibnu, 2010, Komunikasi sebagai Wacana, La Tofi Enterprise, Jakarta.

Hamad, Ibnu, 2010, Komunikasi sebagai Wacana, La Tofi Enterprise, Jakarta.

Littlejohn, Stephen W. and Karen A. Foss, 2009, Theories of Communication, Edisi 9, penerjemah Mohamad Yusuf Hamdan, Salemba Humanika, Jakarta.

Kristianto, JB, dkk (editor), 2004, Esai-esai Bentara, Kompas, Jakarta Pawito, 2007, Metodologi Penelitian Kualitatif, LKiS, Yogyakarta.

Samovar, Larry A. etc, 2010, Communication between Cultures, Edisi 7, penerjemah Indri Margharetha Sidabalok, Salemba Humanika, Jakarta. 